\title{
Obesity aggravates the joint inflammation in a collagen-induced arthritis model through deviation to Th17 differentiation
}

\author{
Joo-Yeon Jhun ${ }^{1 *}$, Bo-Young Yoon ${ }^{3 *}$, \\ Mi-Kyung Park ${ }^{1}$, Hye-Joa Oh ${ }^{1}$, \\ Jae-Kyeong Byun ${ }^{1}$, Seon-Young Lee ${ }^{1}$, \\ Jun-Ki Min', Sung-Hwan Park', \\ Ho-Youn Kim ${ }^{2}$ and Mi-La Cho ${ }^{1,4}$ \\ ${ }^{1}$ The Rheumatism Research Center \\ Catholic Research Institute of Medical Science \\ ${ }^{2}$ Division of Rheumatology \\ Department of Internal Medicine \\ Seoul St. Mary's Hospital \\ The Catholic University of Korea \\ Seoul 137-040, Korea \\ ${ }^{3}$ Department of Internal Medicine \\ Inje University Ilsan Paik Hospital \\ Goyang 411-706, Korea \\ ${ }^{4}$ Corresponding author: Tel, 82-2-2258-7467; \\ Fax, 82-2-599-4287; E-mail, iammila@ catholic.ac.kr \\ *These authors contributed equally to this work. \\ http://dx.doi.org/10.3858/emm.2012.44.7.047
}

Accepted 10 April 2012

Available Online 19 April 2012

Abbreviations: AIA, adjuvant-induced arthritis; BMI, body mass index; CCP, cyclic citrullinated peptide; CIA, collagen-induced arthritis; DIO, diet-induced obesity; EAE, experimental autoimmune encephalomyelitis; HFD, high fat diet; MLR, mixed lymphocyte reaction; $O A$, osteoarthritis; $R A$, rheumatoid arthritis

\begin{abstract}
White fat cells secrete adipokines that induce inflammation and obesity has been reported to be characterized by high serum levels of inflammatory cytokines such as IL- 6 and TNF- $\alpha$. Rheumatoid arthritis (RA) is a prototype of inflammatory arthritis, but the relationship between RA and obesity is controversial. We made an obese inflammatory arthritis model: obese collagen-induced arthritis (CIA). C57BL/6 mice were fed a 60-kcal high fat diet (HFD) from the age of 4 weeks and they were immunized
\end{abstract}

twice with type II collagen (CII). After immunization, the obese CIA mice showed higher arthritis index scores and histology scores and a more increased incidence of developing arthritis than did the lean CIA mice. After treatment with $\mathrm{Cll}$, mixed lymphocyte reaction also showed Cll-specific response more intensely in the obese CIA mice than lean CIA. The anti-CII IgG and anti-CII IgG2a levels in the sera of the obese CIA mice were higher than those of the lean CIA mice. The number of Th17 cells was higher and the IL-17 mRNA expression of the splenocytes in the obese CIA mice was higher than that of the lean CIA mice. Obese CIA mice also showed high IL-17 expression on synovium in immunohistochemistry. Although obesity may not play a pathogenic role in initiating arthritis, it could play an important role in amplifying the inflammation of arthritis through the Th1/Th17 response. The obese CIA murine model will be an important tool when we investigate the effect of several therapeutic target molecules to treat RA.

Keywords: arthritis, experimental; inflammation; mice; obesity; Th17 cells

\section{Introduction}

Obesity has been considered to be one of the most important risk factors for osteoarthritis (OA) in knees. According to the longitudinal studies, hand $\mathrm{OA}$ is also related to obesity (Carman et al.,1994; Oliveria et al., 1999; Grotle et al., 2008). Obesity plays a prominent role due to the overloading of joints and the over-production of pro-inflammatory molecules that can exert detrimental effects on the articular tissues. Activated white adipose tissue increases the synthesis of pro-inflammatory cytokines such as IL-6, IL-1, IL-8, TNF $\alpha$ and IL-18, while regulatory cytokines such as $\mathrm{IL}-10$ are decreased (lannone and Lapadula, 2010). Recent results indicate that IL-6 gene is associated with fat mass in Caucasian men (Andersson et al., 2010). Adipocytes cross-talk with other cells by producing 
and secreting peculiar proteins named adipokines and these are called leptin, resistin and visfatin (lannone and Lapadula, 2010). Researchers are interested in the relationship between obesity and inflammatory arthritis due to a new concept that obesity induces inflammation.

Two case-control studies, one from UK and the other from the Pacific Northwestern US, have suggested a possible association between a high body mass index (BMI) and the risk of rheumatoid arthritis (RA) (Voigt et al., 1994; Symmons et al., 1997). Merete et al. proposed that obesity was selectively associated with risk of anti-cyclic citrullinated peptide (CCP) positive RA (Pedersen et al., 2006). On the other hand, some investigators have suggested that obesity does not influence the likelihood of developing RA. A high BMI is associated with a less severe disease outcome for anti-CCP positive patients with RA (van der Helm-van Mil et al., 2008). In patients with established RA, both a very low BMI and a very high BMI and the percentage of body fat are independently associated with increased disease activity and physical dysfunction (Stavropoulos-Kalinoglou et al., 2009). Unfortunately, epidemiological studies also have shown contradictory findings.

Although both inflammatory arthritis such as RA and obesity have been reported to be characterized by high serum levels of inflammatory cytokines, the frequency of one disorder was not increased in the other. Obesity is not a manipulable variable in human studies and only observation study is possible. It is also hard to assess some effective factors in cohort studies. It is very hard to confirm that obesity is a major risk factor of RA or that obesity has an association with inflammatory arthritis such as RA.

Therefore, we suggest a new murine model, which is called the obese collagen-induced arthritis (CIA) model. In obese CIA mice, arthritis was induced by $\mathrm{Cll}$ collagen using diet-induced obesity (DIO) mice. We compared the obese CIA mice and the lean CIA mice for the severity and incidence of arthritis, the presence of autoantibodies, expression of IL-17 and T cell differentiation. This animal model suggests that obesity be associated with aggravating inflammatory arthritis. We can perform research on the alterations of the cytokine profiles and the immune reaction and experiment on diverse therapeutic interventions using this $\mathrm{CIA}$ animal model.
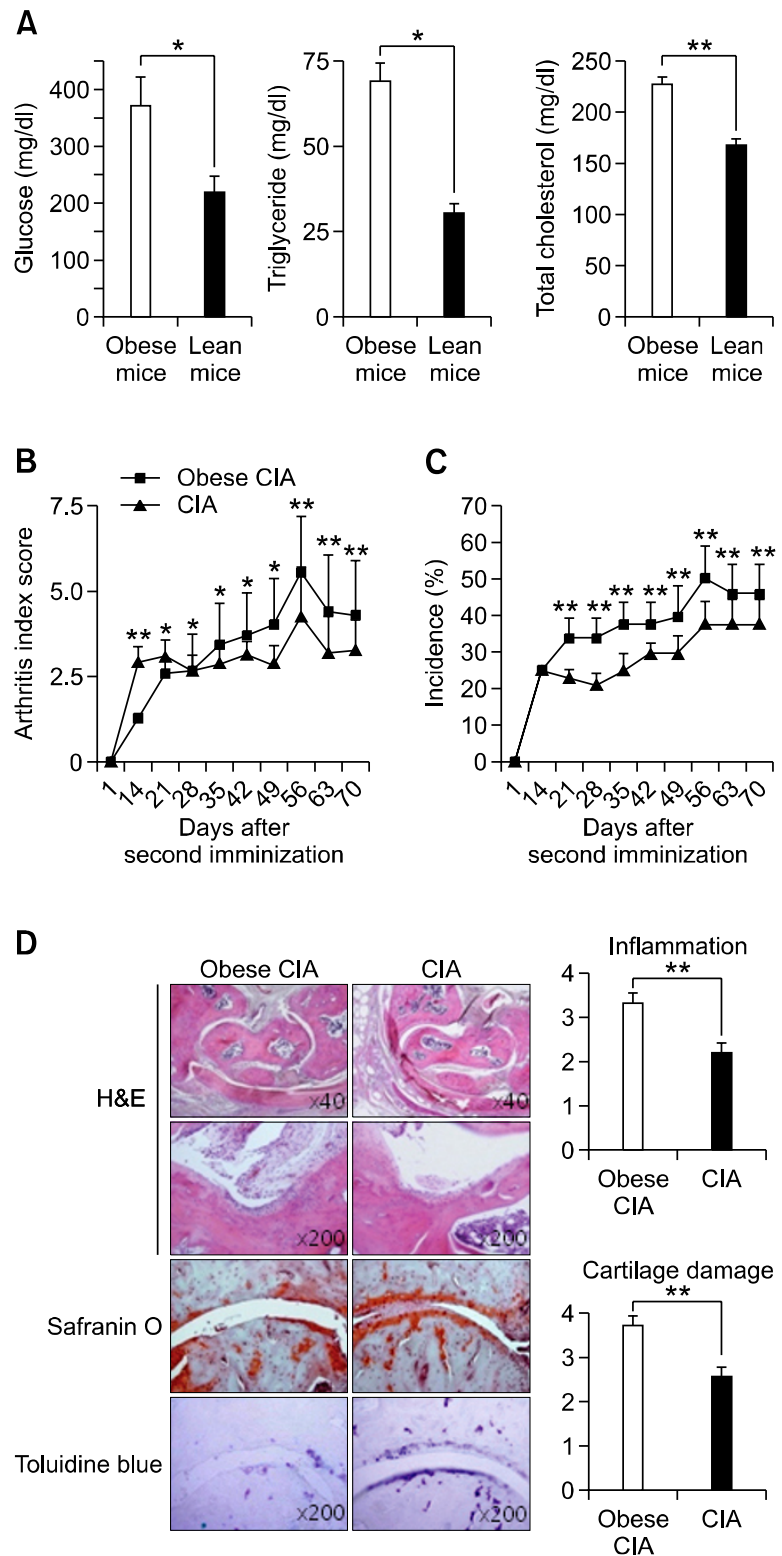

Figure 1. The obesity CIA enhanced induction of arthritis score and incidence of arthritis. The mice were given either standard chow or a high fat diet from 4 weeks of age. Mice sacrifice was done the first time the mouse weighed $30 \mathrm{~g}$. HFD group exhibited significantly higher serum glucose, cholesterol and triglyceride concentrations than standard chow group. (A) The Cll immunization was done the first time when the mouse weighed $30 \mathrm{~g}$. (B, C) The mice were evaluated for the incidence and severity of arthritis. Values are means \pm S.E.M. $(n=6)$. The mean values for the arthritis scores are indicated on the graph. $P<0.01$ compared with the saline control. A representative result of at least three independent experiments is shown. (D) Joint sections from the obese CIA and CIA mice were stained with $\mathrm{H} \& \mathrm{E}$, Safranin $\mathrm{O}$ and Toluidine blue (Original magnification of the H\&E: $40 \times$; Safranin $\mathrm{O}$ and Toluidine blue: $200 \times$ ). 


\section{Results}

\section{Comparison of the arthritis score and the incidence of arthritis between the obese CIA and CIA mice}

We made an obese model. The normal contained $16.0 \%$ fat carolories, whereas $60 \%$ of the calories of HFD were fat calories. Mice sacrifice was done the first time the mouse weighed $30 \mathrm{~g}$. HFD increased glucose $(P=0.0331)$, total cholesterol $(P=0.0237)$ and triglyceride $(P=0.0095)$ levels in the serum as compared with the lean mice group (Figure $1 \mathrm{~A}$ ).

First, we made an obese inflammatory arthritis model. The C57BL/6 (wild-type) mice and the C57BL/6 mice fed a high fat diet $(60 \mathrm{Kcal})$ were immunized with chicken type II collagen (CII) and the development of arthritis was followed for 10 weeks. Both the C57BL/6 (CIA) mice and the C57BL/6 mice fed a high fat diet (obese CIA) mice developed severe arthritis. However, the mice fed a high fat diet had significantly higher arthritis severity scores and a higher incidence of arthritis than that did the $\mathrm{C} 57 \mathrm{BL} / 6$ mice at all time points (Figures 1B and $1 \mathrm{C})$. We assessed synovial inflammation $(P=$ $0.0086)$ by the $H \& E$ stained sections and cartilage damage $(P=0.0050)$ by safranin- $O$ and toluidine blue staining in the knee joints. The histology of the swollen joints in the obese CIA mice showed a massive infiltration of mononuclear and multinuclear cells into the joint and there was synovial pannus formation and progressive articular destruction as compared to that of the CIA mice (Figure 1D).

\section{$\mathrm{T}$ cell responses in the obese $\mathrm{CIA}$ and $\mathrm{CIA}$ mice}

The proliferative recall response to $\mathrm{Cll}$ was performed to assess the degree of the $T$ cell response between the obese CIA and CIA mice.
A

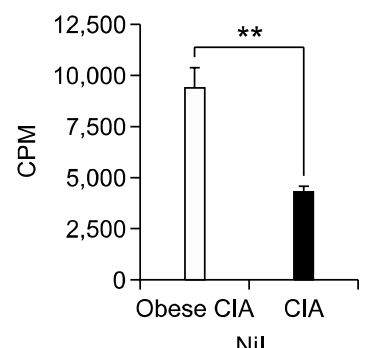

$\mathrm{Nil}$
B

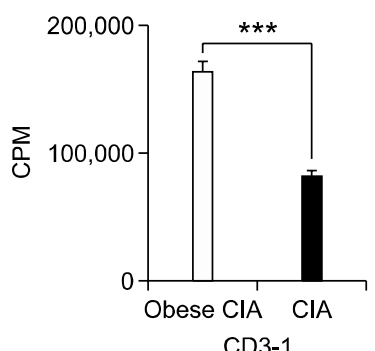

Figure 2. The $T$ cell responses increased in the obese CIA mice. The mice were treated as described in Figure 1. Spleen cells were collected from each group of mice. The cells were cultured without $(A)$ or with 1 $\mu \mathrm{g} / \mathrm{ml}$ anti-CD3 $\mathrm{mAb}(\mathrm{B})$ for $72 \mathrm{~h}$. The T cell proliferative responses were determined by $\left[{ }^{3} \mathrm{H}\right]$ thymidine incorporation assay. The data is presented as the mean counts per $\min (\mathrm{cpm}) \pm \mathrm{SD}$. ${ }^{*} P<0.01,{ }^{* *} P<0.001$ compared with the CIA mice.
The cells obtained from the spleens of the CIA mice with obesity showed increased T cell proliferation in response to anti-CD3 plus anti-CD28 stimulation as well as in response no stimulation as compared with those cells obtained from the CIA mice (Figure 2).

\section{Antigen-specific autoantibodies in the obese CIA and CIA mice}

The concentration of IgG anti-CII, which reflects the Th1 response, was significantly greater in the obese CIA mice than that in the CIA mice $(P=0.0105)$ (Figure 3A). Additionally, the level of Cll-specific IgG2a in the serum, which was higher in the obese CIA mice as compared to that of the CIA mice $(P=$ 0.0045) (Figure 3B).

\section{Quantification of intracellular IL-17 in the splenocytes of the obese CIA and CIA mice}

We then performed intracellular IL-17A staining on the splenocytes from the obese CIA and CIA mice. The IL-17 mRNA levels in the splenocytes of the obese CIA mice were higher than that of the CIA mice $(P=0.0491)$ (Figure 4A). Consistent with the above results, there were more IL-17-secreting cells in the CD4+cell fraction in the obese CIA mice than that in the CIA mice (Figure 4B). Immunohistochemical analysis with the antibodies $\mathrm{IL}-17$ showed comparable numbers of $\mathrm{IL}-17$ expression cells between the obese CIA joint and CIA joint and increased expression of IL-17 in obese CIA joint.

\section{Discussion}

DBA/1 strain mice have been widely used for CIA studies, including the studies involved in the assessment of potential arthritis therapies (Malfait et
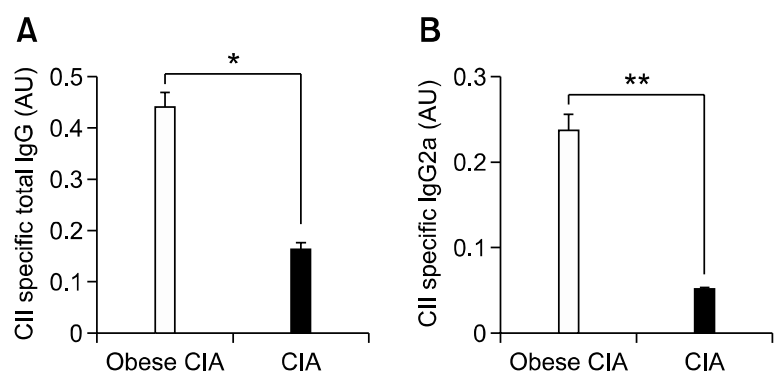

Figure 3. The antigen-specific autoantibodies increased in the obese CIA mice. Ten weeks after the second immunization, sera from the obese $\mathrm{CIA}$ and CIA mice ( $n=6$ for each group) were collected. The Cll-specific total $\lg G(A)$ and $\lg G 2 a(B)$ concentrations were determined in the serum samples of the individual mice by ELISA. The data is expressed as the mean $\pm \mathrm{SD}$. ${ }^{*} P<0.01$ compared with the CIA mice. 

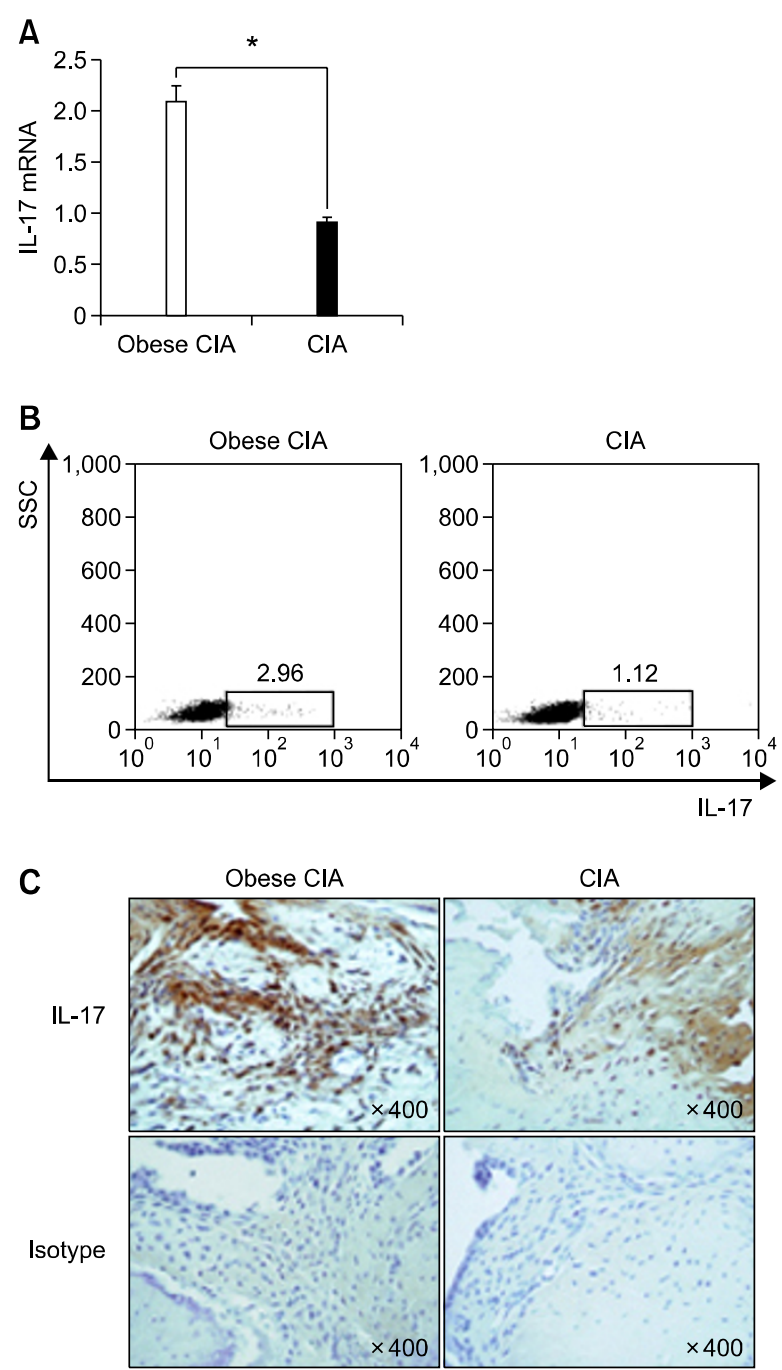

Figure 4. Obesity induces IL-17 in the CIA mice. (A) The expression of IL-17 in the splenocytes obtained from each mouse was determined by real time PCR. The data is expressed as the mean \pm SD. ${ }^{*} P<0.05$, ${ }^{* *} P<0.01$ compared with the CIA mice. (B) The splenocytes from the mice of each group were cultured with $25 \mathrm{ng} / \mathrm{ml} \mathrm{PMA}$ and $250 \mathrm{ng} / \mathrm{ml}$ lonomycin for $4 \mathrm{~h}$. The expression of IL-17 was determined by intracellular flow cytometry analysis. The data is representative of three independent experiments. (C) Immunohistochemical assessment of IL-17 expression in mice joint with $\mathrm{CIA}$ and obese (original magnification, $400 \times)$.

al., 2001). Usually, the DBA/1 strain mice show well induced CIA compared to that of the C57BL/6 mice. Though this study was performed with the C57BL/6 strain, the obese CIA mice well manifested arthritis. It suggested that obesity was related to overcome the resistance to develop CIA in C57BL/6 strain and to be susceptible to inflammation and autoimmunity. Obese CIA model in C57BL/6 strain itself was good evidence that obesity influence on developing autoimmune reaction. Diet-induced obesity (DIO) with C57BL/6 strain induced a good osteoarthritis model expressing high leptin, adiponectin, and IL-1 $\alpha$. DIO showed biochemical, neurobehavioral, musculoskeletal, inflammatory and structural knee joints change (Griffin et al., 2010). This model exhibits that obesity has possibility to accelerate inflammation process through inflammatory adipokines and cytokines.

The C57BL/6 mice were fed a $60 \mathrm{Kcal}$ high fat diet from the age of 4 weeks and they were immunized twice with Cll. After immunization with $\mathrm{Cll}$, the obese CIA mice (C57BL/6 strain) showed a higher arthritis index score and histology score, and there was a more increased incidence of developing arthritis than that of the control (the C57BL/6 strain lean CIA mice) (Figures 1B-1D). This result is important evidence that obesity has an amplifying action in the development of inflammatory arthritis.

The purified splenic lymphocytes from obese CIA mice or lean CIA mice, 10 weeks after the first immunization with CII, were or were not stimulated with anti-CD3. In both conditions (with or without anti-CD3 treatment), the mixed lymphocyte reaction (MLR) of the obese CIA mice was more increased than that of the lean CIA mice (Figure 2). It is well known that $T$ cells have a critical role in developing $\mathrm{CIA}$. In the condition of the treatment with CII, CII specific response was shown in MLR. The splenocytes were proliferated in response to $\mathrm{CII}$ antigen. This result represents that obesity operates immune systems through activation of Cll specific $\mathrm{T}$ cells. Fat cells secret some materials and these react with the immune system and particularly $T$ cells.

Anti-CII lgG and anti-CII lgG2a (autoantibodies of CIA mice) were checked in the serum of both the obese and lean CIA mice. The levels of autoantibody of the obese CIA mice were higher than those of the lean CIA mice (Figure 3). IgG2a type antibodies were produced by the Th1 response. Thus, obesity may cause the T cells of the CIA mice to differentiate toward Th1 cells.

Some investigators have demonstrated that obesity selectively promotes an expansion of the Th17 $\mathrm{T}$ cell sublineage, which is a subset with prominent pro-inflammatory roles in experimentally induced encephalomyelitis (EAE) model (Winer et al., 2009). The T cells from DIO mice expand the Th17 cell pool and produce progressively more IL-17 than that of the lean mice (Winer et al., 2009). Moreover, IL-17 plays an important role in the pathogenesis of RA and CIA. The studies that have employed strategies to neutralize or delete IL-17 have shown that Th17 cells have a pathogenic role in CIA (Nakae et al., 2003; Lubberts et al., 2004; Ju et al., 2008; Sumarac-Dumanovic et al., 2009). Both obesity and CIA activate Th17 cells and this produces 
IL-17. As expected, we observed a more increased number of Th17 cells in the obese CIA mice than that in the lean CIA mice. There was a higher IL-17 mRNA expression in the splenocytes of the obese CIA mice than that of the lean CIA mice (Figure 4A). Moreover, in immunohistochemistry, there was high expression in synovium of obese CIA compared with lean CIA mice (Figure 4C). We suggest obesity amplifies the joint inflammation of CIA mice through Th17 $\mathrm{T}$ cell differentiation and IL-17 production in joint synovium.

It is well established that obesity promotes Th1 deviation and induces inflammatory condition. However, it is not certain that Th17 cell is related with obese-induced inflammation and autoimmunity. Although the precise mechanisms are not clear, EAE model suggested Th17 cells and IL-17 in obese mice have an important role aggravating disease (Winer et al., 2009). According to our results, obese CIA mice show more severe arthritis and an increased incidence of arthritis than do lean CIA mice. This is probably due to Th1 and Th17 differentiation. Sarkar et al. proposed that the Th1/Th2/Th17 balance is important to initiate autoimmunity (Sarkar et al., 2009). Both CIA mice and DIO mice are biased towards Th1 and Th17 differentiation. It is no wonder that the obese CIA mice deviate more to Th1 and Th17 T cells than do the lean CIA mice. We suggest a hypothesis that Th17 cells may be influenced by adipokines and Th17 cells may have some adipokine receptors on cell surface. Clarifying these mechanisms of relationship between adipokines and Th17 cells or IL-17 would be another study.

We made an animal model that represented RA with obesity. In the future, we will investigate the interactions between several cytokines and adipokines using this obese CIA model. Obesity studies have revealed that adipokines are important factors in inflammation. The upregulated resistin at local sites of inflammation and the link between serum resistin, inflammation and the disease activity score suggest a role for resistin in the pathogenesis of RA (Senolt et al., 2007). Bokarewa et al. demonstrated that resistin is a molecule that is accumulated at the site of inflammation and that recombinant resistin injected intraarticularly caused a dose-dependent increase of arthritis (Bokarewa et al., 2005). Neutralization of resistin will be an important therapeutic target in the future. Visfatin, which is also known as pre-B cell colony-enhancing factor, is also another candidate for inducing inflammation in RA. The visfatin gene expression in the synovial tissue and PBMCs of RA patients was significantly higher than that of the controls (Matsui et al., 2008). The positive correlation between the levels of visfatin and resistin suggests that visfatin plays a role in the inflammation of RA (StraburzyńskaLupa et al., 2010). In the future, we will test the adipokines in obese CIA mice and try to find therapeutic modalities through blocking the inflammatory adipokines (Seo et al., 2011).

Other investigators have created adjuvant-induced arthritis (AIA) in obese rats. They tested the effect of the cannabinoid $C B 1$ receptor antagonist rimonbant on AIA in obese rats. They also showed that the inflammation reaction in obese rats is more severe than that in lean rats. The same as in obese AIA rats, it is possible to conduct several therapeutic trials using obese CIA mice (Croci et al., 2007).

In conclusion, obesity plays an addictive role in the inflammation of an inflammatory arthritis model through Cll specific T cell differentiation -Th17 T cells differentiation. IL-17 is a pivotal cytokine to accelerate joints inflammation in obesity. The obese CIA model has value that we can control and investigate the obese condition in an inflammatory arthritis model and we were able to pinpoint several therapeutic target molecules.

\section{Methods}

\section{Animals and diet}

C57BL/6 mice (SLC, Inc., Shozuoka, Japan) that were 4 weeks old were housed in polycarbonate cages. They were fed $60 \mathrm{Kcal}$ fat-derived calories and standard mouse chow (Ralston Purina, St Louis, MO) and water ad libitum. All the experimental procedures were examined and approved by the Animal Research Ethics Committee of the Catholic University of Korea.

\section{Biochemical parameters}

The levels of total serum cholesterol were measured using commercial kits from Wako Co. (Osaka, Japan), and glucose, triglycerides were measured using commercial kits from Asan Pharmaceutical Co. (Hwaseong-si Gyeonggi-do, Korea).

\section{Induction of $\mathrm{ClA}$}

C57BL/6 mice (4 weeks) were purchased from Charles River Breeding Laboratories. CIA was induced as previously described (Inglis et al., 2008). The Cll immunization was done the first time when the mouse weighed $30 \mathrm{gram}$. In brief, An emulsion was formed by dissolving $2 \mathrm{mg} / \mathrm{ml}$ chick collagen type II (CII; Chondrex, Redmond, WA) overnight at $4^{\circ} \mathrm{C}$ in $0.5 \mathrm{M}$ acetic acid, followed by mixing this with an equal volume of CFA (Chondrex, Redmond, WA). The mice were intradermally injected with the emulsion at two sites at the base of the tail and a slightly more anterior location. A second injection as a booster was done 14 days after the primary immunization. 


\section{Mixed leukocyte reaction (analysis on Cll specific T cell response)}

A Cll-specific T cell proliferative response was achieved as previously described (Rosloniec et al., 1996).

Briefly, cells were prepared from the spleens of the obese CIA and CIA mice with arthritis ten weeks after the primary immunization. A single cell suspension was prepared, and $2 \times 10^{5}$ cells/well in 96-well flat bottom plates were cultured in the absence or presence of plate-bound CD3 $1 \mu \mathrm{g} / \mathrm{ml}$ at $37^{\circ} \mathrm{C}$ for $72 \mathrm{~h}$, followed by the incorporation of $\left.25 \mu \mathrm{Ci} / \mathrm{ml}^{3} \mathrm{H}\right]$-thymidine (GE Healthcare, Piscataway, $\mathrm{NJ}$ ) for the last $16 \mathrm{~h}$ of the indicated total culture interval. Then the radioactivity was measured with a Micro Beta (Pharmacia Biotech, Piscataway, NJ).

\section{Clinical assessment of arthritis}

The severity of arthritis was determined by three independent observers. The mice were observed three times a week for the onset and severity of joint inflammation for up to 10 weeks after the primary immunization. The severity of arthritis was assessed on a scale of 0-4 with the following criteria, as was described previously (Rosloniec et al., 1996): $0=$ no edema or swelling, $1=$ slight edema and erythema limited to the foot or ankle, $2=$ slight edema and erythema from the ankle to the tarsal bone, $3=$ moderate edema and erythema from the ankle to the tarsal bone and $4=$ edema and erythema from the ankle to the entire leg. The arthritic score for each mouse was expressed as the sum of the scores of three limbs.

\section{Histopathological analysis of arthritis}

The mouse joint tissues were fixed with $10 \%$ formalin, decalcified in EDTA and embedded in paraffin. The sections were dewaxed using xylene and dehydrated in a graded series of alcohol solutions. The sections were then stained with Harris hematoxylin and eosin (H\&E), Safranin $\mathrm{O}$ and Toluidine blue to detect proteoglyticans. The H\&E stained sections were scored for inflammation and bone erosion. Inflammation was scored according to the following criteria: $0=$ no inflammation, $1=$ slight thickening of the lining layer or some infiltrating cells in the underlying layer, $2=$ slight thickening of the lining layer plus some infiltrating cells in the underlying layer, 3 = thickening of the lining layer, an influx of cells in the underlying layer and the presence of cells in the synovial space and $4=$ synovium highly infiltrated with many inflammatory cells. Cartilage damage was determined using safranin-O staining and Toluidine blue and the extent of cartilage damage was scored according to the following criteria (Rosloniec et al., 1996): $0=$ no destruction, 1 = minimal erosion limited to single spots, $2=$ slight to moderate erosion in a limited area, $3=$ more extensive erosion and $4=$ general destruction.

Immunohistochemistry was performed using the Vectastain ABC kit (Vector Laboratories, Burlingame, CA) tissues were incubated with the anti-IL-17 Abs (Santa cruz Biotechnology Inc., Santa Cruz, CA) and incubated with a biotinylated secondary linking $A b$, and streptavidin-peroxidase complex. The final color product was developed using $\mathrm{DAB}$ chromogen (DAKO, Carpinteria, CA). Images were captured using a DP7 1 digital camera (Olympus,
Center Valley, PA) attached to an Olympus BX4 1 microscope.

\section{Measurement of type II collagen specific antibodies}

The serum levels of type-II-collagen-specific IgG2a and lgG1 were measured by enzyme-linked immunosorbent assay (ELISA), as previously described, with minor modifications (Rosloniec et al., 1996). Briefly, microtiter plates were coated with type II collagen $\left(4 \mu \mathrm{g} / \mathrm{Ml}\right.$ in PBS) at $4^{\circ} \mathrm{C}$ overnight and this was followed by a blocking step for 30 $\mathrm{min}$ at room temperature. The serum samples were then diluted 1:8000 in Tris buffered saline $(\mathrm{pH} \mathrm{8.0)}$ that contained $1 \%$ chicken serum albumin and $0.5 \%$ Tween-20, and the samples were incubated in the microtiter plates for $1 \mathrm{~h}$, after which time the plates were washed five times. The concentrations of IgG2a and IgG1 were measured using mouse IgG2a and IgG1 ELISA Quantitation Kits (Bethyl Laboratories, Montgomery, TX), respectively. Standard serum from the arthritic mice was added to each plate in serial dilutions, and a standard curve was constructed to assign arbitrary units to the levels of anti-type-II-collagen $\lg \mathrm{Ga}$ and $\lg \mathrm{G} 1$. The absorbance values were determined with an ELISA microplate reader operating at $450 \mathrm{~nm}$.

\section{Cell preparation and culture}

Ten weeks after the primary immunization, the mouse spleens were collected for cell preparation and they were washed twice with PBS. The spleens were minced and the red blood cells were lysed with $0.83 \%$ ammonium chloride. The cells were filtered through a cell strainer and then they were centrifuged at $1300 \mathrm{rpm}$ at $4^{\circ} \mathrm{C}$ for $5 \mathrm{~min}$. The cell pellets were resuspended in RPMl 1640 medium and plated in 48-well plates (Corning, NY) at a concentration of $1 \times$ $10^{6}$ cells/well.

\section{Intracellular staining for flow cytometry}

Cell pellets were prepared from the spleens of the obese $\mathrm{CIA}$ and CIA mice with arthritis ten weeks after the primary immunization. The splenocyte cells were stimulated with $50 \mathrm{ng} / \mathrm{ml} \mathrm{PMA}$ and 500 $\mathrm{ng} / \mathrm{ml}$ ionomycin (both from Sigma, St. Louis, MO) and GolgiStop (BD Pharmingen) for $4 \mathrm{~h}$. The cells were stained with anti-CD4 Percp and they were permeabilized with cytofix/Cytoperm solution (BD). Intracellular staining with IL-17 PE was performed in Cytoperm Buffer (BD) according to the manufacturer's protocol. The cells were washed in Cytoperm buffer and in FACS buffer before data acquisition on a FACS Calibur (BD) and the analysis was done using FlowJo software (Tree Star, Ashland, OR).

\section{Expression of mRNA as measured by RT-PCR}

The mRNA was extracted using RNAzolB (Biotex Laboratories, Houston, TX) according to the manufacturer's instructions. Reverse transcription of $2 \mu \mathrm{g}$ aliquots of total mRNA was carried out at $42^{\circ} \mathrm{C}$ using the Superscript reverse transcription system (TaKaRa, Shiga, Japan). The expression of IL-17 mRNA was determined by performing real-time PCR with SYBR Green I. A LightCycler (Roche Diagnostics Mannheim, Germany) was used for the quanti- 
tative analysis of the IL-17 mRNA. The following sense and antisense primers for each molecule were used $\left(5^{\prime} \rightarrow 3^{\prime}\right)$ : IL-17 sense CCT CAA AGC TCA GCG TGT CC, IL-17 antisense GAG CTC ACT TTT GCG CCA AG and $\beta$-actin sense GAAATCGTGCGTGACATCAAG, $\beta$-actin antisense TGTAGTTTCATGGATGCCACAG. The reaction mixtures contained $2 \mu \mathrm{l}$ of LightCycler FastStart DNA mastermix for STBR Green I, $0.5 \mu \mathrm{M}$ of each primer, $4 \mathrm{ml} \mathrm{MgCl}_{2}$ and $2 \mu \mathrm{l}$ of template DNA. All the capillaries were sealed, centrifuged at $500 \mathrm{~g}$ for $5 \mathrm{~s}$ and then amplified in a LightCycler instrument with activation of polymerase $\left(95^{\circ} \mathrm{C}\right.$ for $\left.10 \mathrm{~min}\right)$ as follows: 45 cycles of $10 \mathrm{~s}$ at $95^{\circ} \mathrm{C}, 10 \mathrm{~s}$ at $60^{\circ} \mathrm{C}$, and 10 $\mathrm{s}$ at $72^{\circ} \mathrm{C}$. The double-stranded PCR products were measured during the $72^{\circ} \mathrm{C}$ extension step by detection of the fluorescence associated with the binding of SYBR Green I to the product. The fluorescence curves were analyzed with LightCycler software v.3.0. The expressed levels of IL-17 mRNA were calculated and corrected for the values of the endogenously expressed housekeeping gene ( $\beta$-actin) controls.

\section{Statistical analysis}

The results are expressed as means \pm S.D. (or means \pm S.E.M.). Groups of data were compared using the Mann-Whitney U-test. Differences were considered statistically significant at $P<0.05$.

\section{Acknowledgements}

This research was supported by a grant of the Korea Health Technology R\&D Project, Ministry for Health, Welfare \& Family Affairs, Republic of Korea (grant number A092258).

\section{References}

Andersson N, Strandberg L, Nilsson S, Adamovic S, Karlsson MK, Ljunggren O, Mellstrom D, Lane NE, Zmuda JM, Nielsen C, Orwoll E, Loretzon M, Ohlsson C, Jansson JO. A variant near the interleukin- 6 gene is associated with fat mass in Caucasian men. Int J Obes 2010;34:1011-9

Bokarewa M, Nagaev I, Dahlberg L, Smith U, Tarkowski A. Resistin, an adipokine with potent proinflammatory properties. J Immunol 2005;174:5789-95

Carman WJ, Sowers M, Hawthorne VM, Weissfeld LA. Obesity as a risk factor for osteoarthritis of the hand and wrist: a prospective study. Am J Epidemiol 1994;139:119-29

Croci T, Zarini E. Effect of the cannabinoid CB1 receptor antagonist rimonabant on nociceptive responses and adjuvant-induced arthritis in obese and lean rats. $\mathrm{Br} \mathrm{J}$ Pharmacol 2007;150:559-66

Griffin TM, Fermor B, Huebner JL, Kraus VB, Rodriguiz RM, Wetsel WC, Cao L, Setton LA, Guilak F. Diet-induced obesity differentially regulates behavioral, biomechanical, and molecular risk factors for osteoarthritis in mice. Arthritis Res Ther 2010;12:R130

Grotle M, Hagen KB, Natvig B, Dahl FA, Kvien TK. Obesity and osteoarthritis in knee, hip and/or hand: an epidemiological study in the general population with $10 \mathrm{yr}$ follow-up. BMC Musculoskelet Disord 2008;9:132

lannone F, Lapadula G. Obesity and inflammation--targets for OA therapy. Curr Drug Targets 2010;11:586-98

Inglis JJ, Simelyte E, McCann FE, Criado G, Williams RO. Protocol for the induction of arthritis in C57BL/6 mice. Nat Protoc 2008;3:612-8

Ju JH, Cho ML, Jhun JY, Park MJ, Oh HJ, Min SY, Cho YG, Hwang SY, Kwok SK, Seo SH, Yoon CH, Park SH, Kim HY. Oral administration of type-Il collagen suppresses IL-17-associated RANKL expression of CD4+T cells in collagen-induced arthritis. Immunol Lett 2008;117:16-25

Lubberts E, Koenders MI, Oppers-Walgreen B, van den Bersselaar L, Coenen-de Roo CJ, Joosten LA, van den Berg WB. Treatment with a neutralizing anti-murine interleukin-17 antibody after the onset of collagen-induced arthritis reduces joint inflammation, cartilage destruction, and bone erosion. Arthritis Rheum 2004;50:650-9

Malfait AM, Williams RO, Malik AS, Maini RN, Feldmann M. Chronic relapsing homologous collagen-induced arthritis in DBA/1 mice as a model for testing disease-modifying and remission-inducing therapies. Arthritis Rheum 2001;44: 1215-24

Matsui $H$, Tsutsumi A, Sugihara M, Suzuki T, Iwanami K, Kohno M, Goto D, Matsmoto I, Ito S, Sumida T. Visfatin (pre-B cell colony-enhancing factor) gene expression in patients with rheumatoid arthritis. Ann Rheum Dis 2008;67:571-2

Nakae S, Nambu A, Sudo K, Iwakura Y. Suppression of immune induction of collagen-induced arthritis in IL-17deficient mice. J Immunol 2003;171:6173-7

Oliveria SA, Felson DT, Cirillo PA, Reed JI, Walker AM. Body weight, body mass index, and incident symptomatic osteoarthritis of the hand, hip, and knee. Epidemiology 1999; 10:161-6

Pedersen M, Jacobsen S, Klarlund M, Pedersen BV, Wiik A, Wohlfahrt J, Frisch M. Environmental risk factors differ between rheumatoid arthritis with and without autoantibodies against cyclic citrullinated peptides. Arthritis Res Ther 2006;8:R133

Rosloniec EF, Cremer M, Kang A, Myers LK. Collageninduced arthritis. In: Coligen JE, Kruisbeek AM, Margulies $\mathrm{DH}$, Shevach EM, Strober W, editors. Current protocols in immunology 2001; Chapter 15: Unit 15.5

Sarkar S, Cooney LA, White P, Dunlop DB, Endres J, Jorns JM, Wasco MJ, Fox DA. Regulation of pathogenic IL-17 responses in collagen-induced arthritis: roles of endogenous interferon-gamma and IL-4. Arthritis Res Ther 2009;11: R158

Senolt L, Housa D, Vernerová Z, Jirásek T, Svobodová R, Veigl D, Anderlova K, Muller-Ladner U, Pavelka K, Haluzik $M$. Resistin in rheumatoid arthritis synovial tissue, synovial fluid and serum. Ann Rheum Dis 2007;66:458-63

Seo JB, Choe SS, Jeong HW, Park SW, Shin HJ, Choi SM, Park JY, Choi EW, Kim JB, Seon DS, Jeong JY, Lee TG. Ant-obesity effects of Lysimachia foenum-graecum 
characterized by decreased adipogenesis and regulated lipid metabolism. Exp Mol Med 2011;43:205-15

Sumarac-Dumanovic M, Stevanovic D, Ljubic A, Jorga J, Simic M, Stamenkovic-Pejkovic D, Stracevic V, Trajkovic V Micic D. Increased activity of interleukin-23/interleukin-17 proinflammatory axis in obese women. Int J Obes 2009;33: 151-6

Straburzyńska-Lupa A, Nowak A, Pilaczyńska-Szcześniak $Ł$, Straburzyńska-Migaj E, Romanowski W, Karolkiewicz J, Sliwicka E. Visfatin, resistin, hsCRP and insulin resistance in relation to abdominal obesity in women with rheumatoid arthritis. Clin Exp Rheumatol 2010;28:19-24

Stavropoulos-Kalinoglou A, Metsios GS, Panoulas VF, Nevill AM, Jamurtas AZ, Koutedakis Y, Kitas GD. Underweight and obese states both associate with worse disease activity and physical function in patients with established rheumatoid arthritis. Clin Rheumatol 2009;28:439-44
Symmons DP, Bankhead CR, Harrison BJ, Brennan P, Barrett EM, Scott DG, Silman AJ. Blood transfusion, smoking, and obesity as risk factors for the development of rheumatoid arthritis: results from a primary care-based incident case-control study in Norfolk, England. Arthritis Rheum 1997;40:1955-61

van der Helm-van Mil AH, van der Kooij SM, Allaart CF, Toes $\mathrm{RE}$, Huizinga TW. A high body mass index has a protective effect on the amount of joint destruction in small joints in early rheumatoid arthritis. Ann Rheum Dis 2008;67:769-74

Voigt LF, Koepsell TD, Nelson JL, Dugowson CE, Daling JR. Smoking, obesity, alcohol consumption, and the risk of rheumatoid arthritis. Epidemiology 1994;5:525-32

Winer S, Paltser G, Chan Y, Tsui H, Engleman E, Winer D, Dosch HM. Obesity predisposes to Th17 bias. Eur J Immunol 2009;39:2629-35 